\title{
Legal Environment Analysis of Basic Research in China
}

\author{
Li Lingjuan*, Zhang Changran, Luo Xianjue \\ School of Public Policy and Management, University of Chinese Academy of Sciences, Beijing, China \\ Email address: \\ 1lj791010@ucas.ac.cn (Li Lingjuan), zhangchangran18@mails.ucas.ac.cn (Zhang Changran), luoxj@ucas.ac.cn (Luo Xianjue) \\ ${ }^{*}$ Corresponding author
}

\section{To cite this article:}

Li Lingjuan, Zhang Changran, Luo Xianjue. Legal Environment Analysis of Basic Research in China. American Journal of Applied Scientific Research. Special Issue: Science and Law (Review of Several Issues of Contemporary Science and Technology Law).

Vol. 6, No. 1, 2020, pp. 13-23. doi: 10.11648/j.ajasr.20200601.12

Received: February 16, 2020; Accepted: February 27, 2020; Published: March 10, 2020

\begin{abstract}
Basic research will become a leading force and strategic engine for the future world development. The establishment of the legal system of basic research provides an all-round institutional guarantee for the vigorous development of basic research. The development of basic research cannot be separated from a good legal environment. Two dimensions of legal environment analysis of basic research are constructed: The first is the composition of the legal subject of basic research and the nature of basic research behavior, the second is the typical problem of basic research in China and the legal system it requires. Based on the above research frame, There are five main legal problems about basic research in Chnia: The lack of legislation on basic research subjects (scientific research institutions); The actual weakening of basic research guarantees under the existing governance framework; The lack of legislation for scientific research funding and the lack of supervision; The lack of integrity in the legal environment for basic research; The legal system of transformation of achievements focuses on dislocation. In order to solve the above problems, legislation should pay attention to the importance of basic research, guarantee the independence of basic research funding institutions and research institutions, and establish independent research funding management laws. Create an honest legal environment and social atmosphere conducive to basic research, establish a stable and effective legal system for protecting and using basic research results.
\end{abstract}

Keywords: Basic Research, Legal Governance, Legal Environment, Investment Mechanism, Integrity

\section{Introduction}

In his report to the 19th CPC national congress, general secretary Xi Jinping stressed that, " China should aim at the forefront of world science and technology and strengthen basic research. Achieving major breakthroughs in both prospective basic research and Leading original research results. " Chinese Premier Li Keqiang said during a visit to the Institute of Physics, Chinese Academy of Sciences, "The depth and breadth of a country's basic research determines the impetus and vitality of the country's academician innovation." China is implementing an innovation-driven strategy. In order to meet the strong demand for source innovation in various fields of economic and social development and national security, China has formulated the "13th Five-Year Plan" National Basic Research Special Plan which will further enhance the supply capacity of innovation sources and promote the overall prosperity of basic research.
Basic research will become a leading force and strategic engine for the future world development. The establishment of the legal system of basic research provides an all-round institutional guarantee for the vigorous development of basic research. [1]

\section{Basic Research and China's Basic Research National System}

\subsection{Basic Research Content and Function Development}

In November 1944, America President Roosevelt wrote a letter to OSRD Director Vannevar Bush seeking recommendations on how research and the research infrastructure established to support America's war effort could be "Profitably employed in times of peace". Bush's response, Science: The Endless Frontier, laid out a framework that asserted the essential role of scientific 
progress in meeting the nation's economic, national security, and social needs. [2] Since then, the US federal government has invested heavily in basic research, applied research, infrastructure and education. These federal investments helped create a large, multisectoral U.S. tech network including official institutions, world's leading colleges and universities, private companies, non-profit organizations, federal national laboratories. The United States has begun to rise as a global leader in science and technology.

The Chinese government conducted the first national science and technology census in 1985, In the statistical indicators of the census, the concept of scientific research classification of UNESCO was formally introduced for the first time, and this was used as one of the basis for policy formulation and scientific and technological system reform. [3] According to UNESCO, basic research is primarily experimental or theoretical work undertaken to obtain new knowledge of the basic principles of objective phenomena and observable facts. It is not intended for any recent specialized or specific application or use. In the 1990s, with the rapid development of science, the scale of scientific research has been increasing, and the relationship between science and economic growth has become increasingly close. The intervention of the state in basic research has been gradually strengthened, and the pure basic research, which is based entirely on the interests of scientists, has been gradually reduced. The Decision of the CPC Central Committee and the State Council on Accelerating Scientific and Technological Progress issued on May 6, 1995 states "In the current period, basic research must put national goals at an important place." The second National Basic Research Working Conference held in 2000 further clarified that basic research can be divided into exploratory basic research and strategic basic research, the former is based on the free exploration of scientists, and the latter is the research work carried out from the country's major strategic needs. [4] The conference pointed out that China has four national goals for basic research: The first is that China should obtain its due status at the forefront of international science and rank among the world's leading scientific powers; The second is to provide strong scientific support for China's economic, social and security goals; The third is to train outstanding scientists and engineers that meet the development needs of the $21 \mathrm{st}$ century. The Outline of National Medium- and Long-Term Scientific and Technological Development Planning implemented in 2006 further affirmed the goals and functions of the basic research mentioned above. The "13th Five-Year Plan" National Basic Research Special Plan jointly issued by the Ministry of Science and Technology and other three departments in 2017 clearly stated that basic research will be supported continuously and stably during the 13th five-year plan period, and the country will focus on its long-term strategic development.

\subsection{National Basic Research System of China}

\subsubsection{Stability Agency Funding for Basic Research}

The government's role in the scientific system is to make knowledge production for the benefit of society efficiently. The government should determine the development priorities for a certain period of time, so as to strategically guide the direction of knowledge production, serve the comprehensive development of science, economy, and society, and improve national competitiveness.

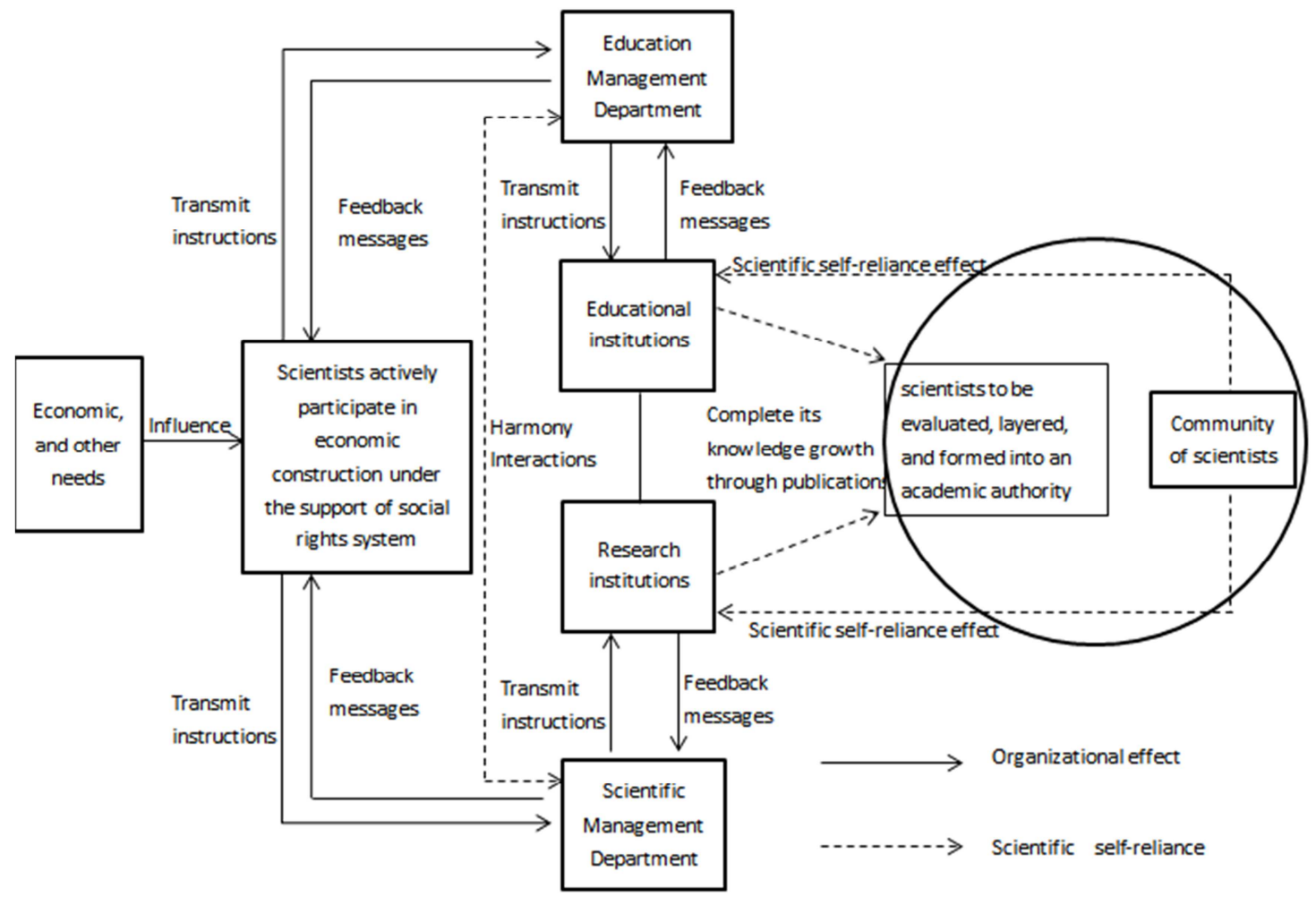

Figure 1. China's Stability Agency Funding Model for Basic Research. 
Under the stability agency funding model for basic research, for a period of time, the economic and social development needs are communicated to the educational administration and the scientific administration in the form of financial allocations. The education management department transmits instructions to educational institutions, and the scientific management department transmits instructions to scientific research institutions. Educational institutions and research institutions complete knowledge growth through publications which promotes the formation of a scientific community, enabling scientists to be evaluated, layered, and formed into an academic authority system. On the other hand, as a professional community, the scientific community has relatively independence and the same values, and plays an important role in the allocation of scientific resources. The scientific community feeds back to educational and scientific research institutions through forming scientific research paradigms and scientific research behavior norms, cultivating basic research talents, forming and disseminating scientific knowledge, producing major scientific achievements, and providing scientific and technological decision-making consultation. In order to meet the needs of social and economic development, and promote the overall scientific and technological progress of society.

Different from the funding model of science and technology planning funding for basic research, the stability agency funding model focuses on regulating and guiding basic research institutions. This funding mode mainly focuses on the evaluation of scientific knowledge, scientific and technological achievements, and the cultivation of scientific and technological talents. Under this model, the state steadily invests research funds in basic research institutions in the name of "operating expense ", research institutions are very free in managing their funds, and institutions can use these funds freely in ways they see fit. The disadvantage of this model is that the funding is mainly used for teaching and personnel training, and only a small proportion of the funding is used for research, which fails to provide a stable supporting environment for basic research. At present, all countries increase the stability agency funding for basic research institutions through legislation to provide institutional guarantee for the development of basic research.

\subsubsection{Science and Technology Planning Funding for Basic Research}

China's science and technology plans and special projects to support basic research include the National Natural Science Foundation of China, the Ministry of Science and Technology's key basic research and development plan, the National Key Laboratory, National Major Scientific Project, National Strategic Pilot Sci-tech Project, etc. Among them, National Key Laboratory, National Major Scientific Project, National Strategic Pilot Sci-tech Project are stability support. The National Natural Science Foundation of China, the Ministry of Science and Technology's key basic research and development plan are competitive funds.

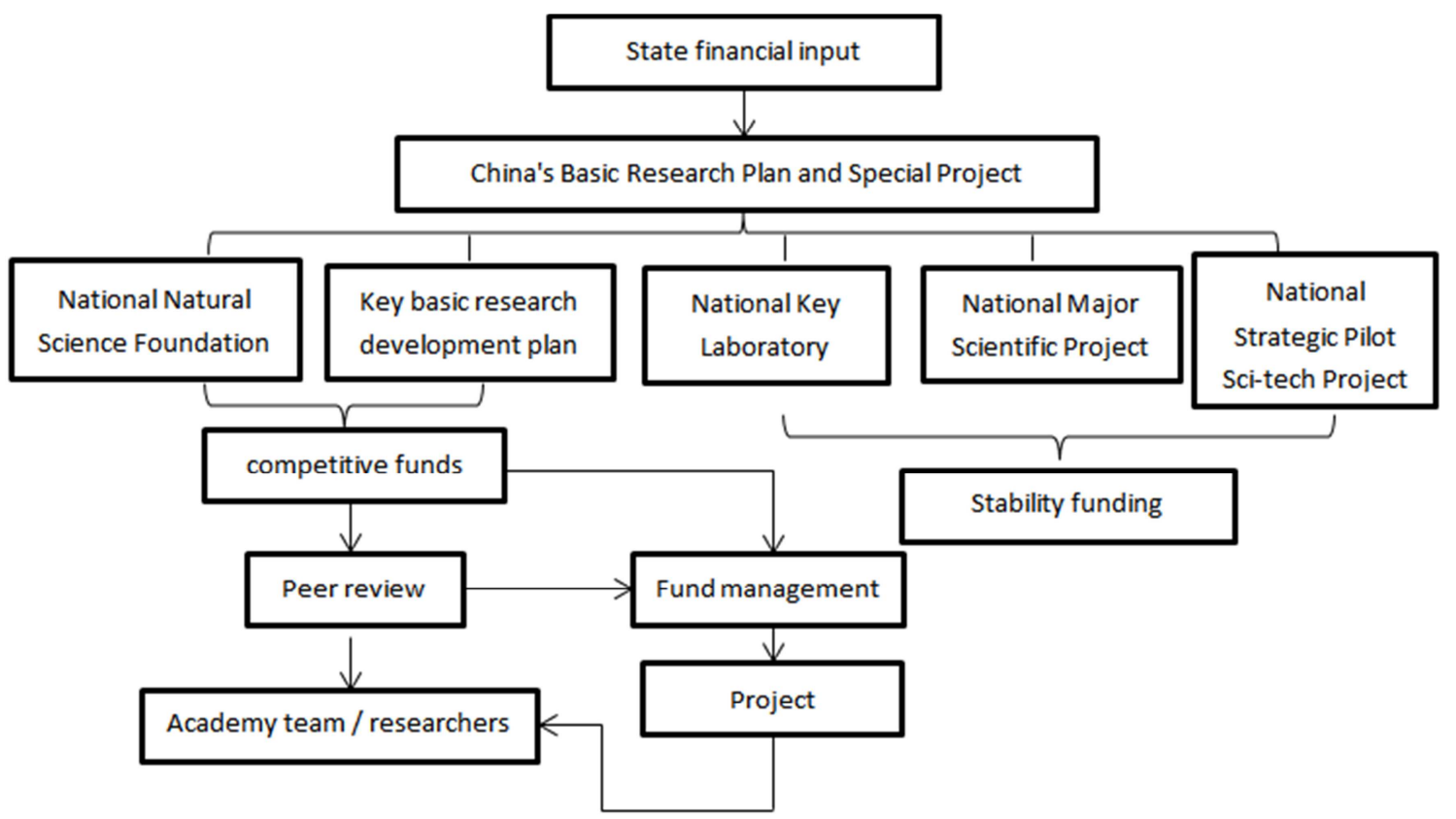

Figure 2. China's Science and Technology Planing Funding Model for Basic Research.

Funding models for competitive science and technology planning funding for basic research are generally obtained by researchers applying for competitive projects from public research funding management departments. The purpose of applying for projects and obtaining approval is to obtain funding through this competitive mechanism. The advantages of competitive funding are twofold: First, to promote collaboration among research institutions by selecting projects and scientists, or through project-based interdisciplinary collaboration; Second, some flexible funding mechanisms have been added to facilitate realignment and allocation of funds. However, the problems 
and challenges caused by competitive funding mainly include: Project funding from government, industry or other external investors reduces the space for universities and public research institutions to arrange their research agendas autonomously and to some extent diverges the traditional structure of the science community in a scientific system; The extensive use of project funding has raised concerns about whether it will affect the basic capabilities of scientific knowledge production and hinder the development of scientific knowledge systems. It also leads to concerns about how to stabilize the scientific research team and support the infrastructure for scientific knowledge production.

\section{Several Basic Legal Issues of Basic Research in China}

The legal environment research of basic research needs to solve the following core legal issues. First of all, from the perspective of basic research funding, what is the legal relationship between the basic research technology program funder and the grantee. Secondly, whether the management behavior of the competent authority in the implementation of the basic research technology plan is an administrative act, whether it has the power of administrative punishment, and the corresponding legal basis. Thirdly, from the perspective of scientific and technological plan holders, that is, research institutions. What is the scientific research institution's definition, what is its legal status, and what are its basic rights and obligations? Is the scientific research institution special compared with other institutions. These issues are related to the fundamentals of the basic research legal system and the basis for conducting a basic research legal environment analysis.

\subsection{Forms and Legal Nature of Funding for Basic Research}

Funding for basic research often comes in the form of scientific research contracts, which are generally signed by state funding agencies and scientific research institutions to regulate the rights and obligations of both parties in order to achieve certain technological research and development objectives. On the one hand, the funding source for scientific research contracts is public financial investment, which is signed for the purpose of achieving public interest. On the other hand, the implementation process of scientific research contracts reflects a strong administrative color, for example, relevant management agencies have the power to supervise, and they have compulsory requirements in terms of results acceptance, evaluation, and ownership. Thirdly, the trustee's scientific research institution has very limited and weakened rights in the control of funds and remuneration for scientific research activities after receiving funding. So what is the nature of a research contract?

Due to the unclear positioning of the nature of scientific research contracts, many problems have arisen in the scientific and technological system. Such as the abuse of scientific research funds, corruption and other problems, and the inefficient transformation of scientific and technological achievements. It is important to clarify the legal nature of research contracts. We cannot deny the private law nature of scientific research contracts because of a large number of administrative factors in scientific research contracts. The contract system has experienced a decline from contract liberalism to the tide of liberalism in the twentieth century. The importance of contract as a way of organizing economic activities is decreasing, while it is more and more common to organize economic activities by vertical management mechanism. "The meaning of the contract has also changed drastically."[5] "When the state's ownership of social resources replaces private ownership, a society may also severely restrict private contractual freedoms. The society may make mandatory provisions on all the terms of the contract... Even if the contract clauses are not comprehensively enforced, the state may enforce some specific contract clauses. Only the remaining clauses can be determined by the parties. "[6] Even so, the state must strive to ensure that deals are reached in an acceptable manner, and that they are not so strong that they can replace equitable transactions with substantial coercion. Since the liberalism contained in the contract is the core value of the contract and the cornerstone of the contract system, how to reflect the laws of basic research in scientific research contracts, determine the boundaries between mandatory clauses and free clauses, in order to recognize, respect and protect the autonomous rights of research subjects, including the autonomy of funds and the right to obtain compensation, so as to increase the enthusiasm of scientific researchers is the main problem of basic research law.

\subsection{Management Behavior of the Whole-Process of Basic Research and Its Legal Nature}

How to characterize the whole-process management behavior in the implementation of government-funded research projects, Is it an administrative act, and does it have the right to impose administrative penalties on scientific research acts that violate relevant regulations? In fact, this involves the relationship between government and science, and how the government can effectively support scientific development. The government has set up a science fund to fund basic research and some applied research, so how should the science fund be positioned and managed? Whether it is managed by scientists, with scientific development as the ultimate goal, or should be under government control that the ultimate goal is to improve the well-being of the entire country. There is no doubt that the important role of basic research in improving the country's core competitiveness and social development has given the answer. The point is that government control is different from direct government intervention. How to ensure the government's control over scientific research while making scientific research conform to the law of research and independent from direct government intervention? This involves the legal attributes of government funding, the organizational structure of scientific funds, the principles of operation, and rights and obligations. 
China's main institution for promoting basic research and development is the National Natural Science Foundation of China, article 16 of the 1993 Law of the People's Republic of China on Science and Technology Progress (hereinafter referred to as the "Science and Technology Progress $\left.L a w^{\prime \prime}\right), " T h e$ State sets up a natural science fund to fund basic research and scientific frontier exploration, and to train scientific and technological personnel". However, the "Science and Technology Progress Law" only provides principles and does not provide detailed regulations on the organizational structure, rights and obligations of the National Natural Science Foundation of China. Since then, the State Council has promulgated the Regulations of the National Natural Science Foundation of China in 2007, it clarified that the National Natural Science Foundation of China is responsible for the organization, implementation, and evaluation of the funding plans and projects of the Natural Science Foundation. In 2018, according to the "Deepening Party and State Institutional Reform Program", the Natural Science Foundation of China was changed from a public institution directly under the State Council to be managed by the Ministry of Science and Technology. The administrative affiliation of the Natural Science Foundation of China has been adjusted, but its legal attributes have not been reflected in legislation. Compared with the detailed rules and power restriction rules of the National Science Board and Director of the Foundation in the American Science Foundation Act, the legal attributes of the National Natural Science Foundation of China, The organization system of the Fund Committee has not been reflected in the legislation, and the important role of the Natural Science Foundation as a scientific decision-making consultation has not been reflected. The organization and implementation of basic research by the National Natural Science Foundation of China is a management act and an administrative act in the sense of administrative law. This is because the National Natural Science Foundation of China is not an administrative agency, and it has extremely limited administrative penalty powers within the scope of legal authorization.

\subsection{The Subject of Research and Its Legal Nature}

Universities and research institutions (specially referred to in the text as universities and research institutions funded by the central government) are the main subjects of basic research in China. As the main subject of government-funded technology programs. Universities and research institutions need to clarify their rights and obligations in the funding of science and technology projects, including the autonomy of research institutions, the right to use research funds, the right to remuneration, the right to reward, and the intellectual property rights of research results. Among them, what is particularly important is the legal nature of a national research institution as a subject of basic research, and how does its autonomy in scientific research manifest itself? In China's existing legal system, universities as the subject of research are regulated by the Higher Education Law, and their status and rights and obligations are relatively clear. However, for scientific research institutions, it lacks a clear legal basis. The relevant legal provisions are found in the General principles of civil law of the people's Republic of China and the Interim Regulations on Registration and Management of Public Institutions. Taking the Chinese Academy of Sciences as an example, "If only simply based on the General Principles of Civil Law treat the Chinese Academy of Sciences as a civil legal subject of a public entity legal person, obviously, it is difficult to reflect the overall importance, political and key requirements of the establishment of the national academy of sciences. As a public institution directly under the State Council, its functions and powers have not been legalized, and it is difficult to reflect the role of the Chinese Academy of Sciences as a national strategic scientific and technological force to serve national strategic decision-making."'[7] If a scientific research institute has a clear legal basis which can make the activities of scientific research institutions rule-based and law-based. This is conducive to scientific research institutions to follow the rules of scientific research and to avoid interference and restriction by administrative forces and conducive to scientific research institutions in the main position in the transformation of scientific and technological achievements. [8]

\section{Typical Legal Problems of Basic Research System in China}

\subsection{Analytical Framework of Typical Basic Research Legal Issues}

The analysis of typical legal issues in basic research is actually an analysis of system requirements from the perspective of key links in basic research activities. Basic research is vital to the achievement of national strategic goals, and the supporting of national basic research should be regarded as an important national policy. Against this background, what type of legal system does basic research need to establish in areas such as input mechanism, fund management system, scientific research integrity system and results protection and application etc. For example, whether the country needs the "high-risk, high-reward" research to provide corresponding institutional protection through legislation. For scientific research misconduct in basic research, should the scientific community conduct self-examination and self-correction or entrust the administrative organ to investigate and deal with it through legislation. Is there a legal basis for scientific misconduct regulation, how to characterize it, and so on. From the above perspective, the particularity of basic research is described, and the development trend and challenges of basic research are combined to describe the unique legal system analysis framework of basic research. 


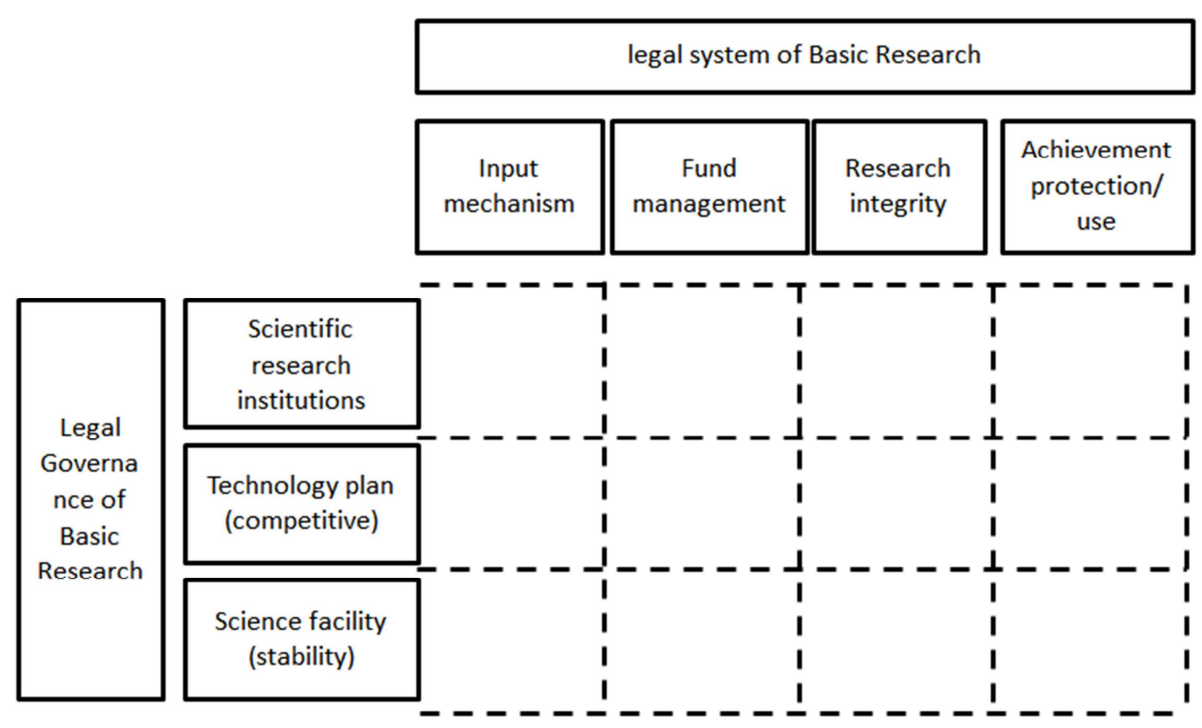

Figure 3. Analysis Model of Typical Legal Environment for Basic Research.

\subsection{Status Quo and Key Issues of Legislation in China's Basic Research}

At present, the relevant legislation in China's basic research fields are Scientific and Technological Progress Law of the People's Republic of China, General Principles of the Civil Law of the People's Republic of China, Higher Education Law of the People's Republic of China, Law of the People's Republic of China on the Promotion of Application of Scientific and Technological Achievements, Patent Law of the People's Republic of China, Budget Law of the People's Republic of China, Accounting Law of the People's Republic of China, Audit Law of the People's Republic of China, Supervision Law of the People's Republic of China etc. The administrative regulations include the Regulations of the
National Natural Science Foundation of China and the Regulations of the People's Republic of China on the Implementation of the Audit Law. The policy documents include the Notice on Printing and Distributing Certain Provisions of the Law of the People's Republic of China on Promoting the Transformation of Scientific and Technological Achievements issued by the State Council, and the Notice on Printing and Distributing the Special Plan for National Basic Research of the 13th Five-Year Plan issued by the Ministry of Science and Technology, the Several Opinions on Further Strengthening the Construction of Scientific Research Integrity issued by the General Office, see the table below for details.

Table 1. Legislative Status in the Field of Basic Research in China.

\begin{tabular}{|c|c|c|c|c|c|}
\hline $\begin{array}{l}\text { Basic } \\
\text { research }\end{array}$ & Subject system & Input system & research funding & $\begin{array}{l}\text { Research } \\
\text { integrity }\end{array}$ & Results protection / utilization \\
\hline law & $\begin{array}{l}\text { Scientific and } \\
\text { Technological Progress } \\
\text { Law, Higher Education } \\
\text { Law }\end{array}$ & $\begin{array}{l}\text { Budget Law, Scientific } \\
\text { and Technological } \\
\text { Progress Law }\end{array}$ & $\begin{array}{l}\text { Accounting Law, Audit } \\
\text { Law, Supervision Law }\end{array}$ & $\begin{array}{l}\text { Scientific and } \\
\text { Technological } \\
\text { Progress Law }\end{array}$ & $\begin{array}{l}\text { Scientific and Technological } \\
\text { Progress Law, Promotion of } \\
\text { Application of Scientific and } \\
\text { Technological Achievements law, } \\
\text { Patent Law, Copyright Law }\end{array}$ \\
\hline Regulations & $\begin{array}{l}\text { Interim Regulations on the } \\
\text { Administration of } \\
\text { Registration of Institutions }\end{array}$ & $\begin{array}{l}\text { Regulations of the } \\
\text { National Natural } \\
\text { Science Foundation }\end{array}$ & $\begin{array}{l}\text { Regulations for the } \\
\text { Implementation of the } \\
\text { Audit Law of the } \\
\text { People's Republic of } \\
\text { China }\end{array}$ & none & $\begin{array}{l}\text { Regulations on the Implementation } \\
\text { of the Patent Law, Regulations for } \\
\text { the Implementation of the Copyright } \\
\text { Law }\end{array}$ \\
\hline rule & $\begin{array}{l}\text { Administrative Measures } \\
\text { for Public Institutions }\end{array}$ & $\begin{array}{l}\text { Measures for the } \\
\text { Administration of } \\
\text { National Key Basic } \\
\text { Research and } \\
\text { Development Plans }\end{array}$ & $\begin{array}{l}\text { Measures for the } \\
\text { Administration of } \\
\text { National Key Basic } \\
\text { Research and } \\
\text { Development Plans, } \\
\text { Measures for the } \\
\text { Administration of } \\
\text { Special Funds for } \\
\text { National Key Basic } \\
\text { Research and } \\
\text { Development Plans }\end{array}$ & $\begin{array}{l}\text { Measures for } \\
\text { the } \\
\text { Prevention } \\
\text { and Treatment } \\
\text { of Academic } \\
\text { Misconduct in } \\
\text { Colleges and } \\
\text { Universities }\end{array}$ & $\begin{array}{l}\text { Measures for registration of } \\
\text { scientific and technological } \\
\text { achievements }\end{array}$ \\
\hline $\begin{array}{l}\text { Policy/ } \\
\text { normative } \\
\text { documents }\end{array}$ & $\begin{array}{l}\text { Outline of National } \\
\text { Innovation-Driven } \\
\text { Development Strategy, }\end{array}$ & $\begin{array}{l}\text { Notice of the Ministry } \\
\text { of Science and } \\
\text { Technology on }\end{array}$ & $\begin{array}{l}\text { "Several Opinions on } \\
\text { Improving and } \\
\text { Strengthening Central }\end{array}$ & $\begin{array}{l}\text { "Several } \\
\text { Opinions on } \\
\text { Further }\end{array}$ & $\begin{array}{l}\text { Several opinions on the } \\
\text { implementation of independent } \\
\text { innovation incentive distribution }\end{array}$ \\
\hline
\end{tabular}




\begin{tabular}{|c|c|c|c|c|c|}
\hline $\begin{array}{l}\text { Basic } \\
\text { research }\end{array}$ & Subject system & Input system & research funding & $\begin{array}{l}\text { Research } \\
\text { integrity }\end{array}$ & Results protection / utilization \\
\hline & $\begin{array}{l}\text { Implementation Plan for } \\
\text { Deepening the Reform of } \\
\text { the Science and } \\
\text { Technology System, } \\
\text { "Notice of the State } \\
\text { Council on Establishment } \\
\text { of Institutions", Several } \\
\text { Opinions of the State } \\
\text { Council on } \\
\text { Comprehensively } \\
\text { Strengthening Basic } \\
\text { Research }\end{array}$ & $\begin{array}{l}\text { Printing and } \\
\text { Distributing the } \\
\text { National Basic } \\
\text { Research Special Plan } \\
\text { for the 13th Five-Year, } \\
\text { Several Opinions of } \\
\text { the State Council on } \\
\text { Comprehensively } \\
\text { Strengthening Basic } \\
\text { Research }\end{array}$ & $\begin{array}{l}\text { Financial Research } \\
\text { Projects and Fund } \\
\text { Management", etc. } \\
\text { Several Opinions of } \\
\text { the State Council on } \\
\text { Comprehensively } \\
\text { Strengthening Basic } \\
\text { Research }\end{array}$ & $\begin{array}{l}\text { Strengthening } \\
\text { the } \\
\text { Construction } \\
\text { of Scientific } \\
\text { Research } \\
\text { Integrity", etc. }\end{array}$ & system in enterprises \\
\hline
\end{tabular}

As can be seen from the above table, the current status of legislation related to basic research:

The first is the lack of legislation on basic research subjects (scientific research institutions). As far as scientific research institutions that are important carriers of basic research are concerned, the existing legal and policy documents attach great importance to the establishment of the governance system of modern scientific research institutes. Such as the National Innovation-Driven Development Strategy Outline, Deepening Science and Technology System Reform Implementation Plan are involved. The Science and Technology Progress Law distinguishes scientific and technological research and development institutions established with financial funds from other scientific research institutions in legislation, and makes different legal provisions on their management. However, there is still a lack of rules to guarantee the autonomy of scientific research institutions. In addition, for scientific research institutions established with financial funds, The research institutions that are directly under the State Council and the research institutions that are general institutions of the State Council are not distinguished in terms of positioning, rights and obligations. Therefore, the legislative confirmation of the legal nature of scientific research institutions is a key step in the reform of national science and technology resources and investment in science and technology. It is also the institutional basis for enjoying legal rights and obligations as the legal subject.

The second is the actual weakening of basic research guarantees under the existing governance framework. Each of the major innovative countries and regions in the world has explored a relatively comprehensive basic research organization management system and project management process according to its own political and economic characteristics and historical and cultural conditions, and has formed its own unique experience and means of optimizing the allocation of scientific and technological resources. China has established the Natural Science Foundation of China to fund basic research and scientific frontier exploration, and the source of funds mainly depends on budget allocations. In 2018, according to the Deepening the Reform Program of the Party and State Organizations, the Natural Science Foundation of China was changed from a public institution directly under the State Council to the Ministry of Science and Technology. From the perspective of changes in institutional settings, basic research has been over-interpreted as a field of free exploration driven by curiosity, ignoring the importance of strategically-oriented basic research. While integrating the original 973 funding plan into the key R\&D plan, some critics believe that this setting will transfer funds from key basic research to business-oriented research or other research areas that do not require government support. This conflicts with the government's science and technology plans and development goals.

The third is the lack of legislation for scientific research funding and the lack of supervision. In the field of scientific research, China currently does not have a systemic law on the establishment, approval, appropriation of funds, and supervision responsibility of scientific research projects. The current fund management is mainly based on the relevant provisions of the Accounting Law, the Audit Law, and the Supervision Law which emphasizes the need to implement the entire budget management process of ex-ante budget evaluation, in-event fund supervision and financial inspection, post-event financial acceptance and audit, and to prevent scientific research corruption. However, since the use of scientific research funds is different from administrative funds, how to reflect the autonomy and remuneration of scientific research in the management of scientific research funds is a key issue. The lack of special legislation on scientific research funding directly leads to the confusion of scientific research project management.

The fourth is the lack of integrity in the legal environment for basic research. In 2006, the Ministry of Science and Technology promulgated the Measures for Dealing with Misconduct in Scientific Research in the Implementation of National Science and Technology Plan (Trial), which is the first administrative regulation to regulate misconduct in scientific research. Articles 57, 70, and 71 of the 2007 Scientific and Technological Progress Law are all related to the integrity of scientific research. In 2008, the Ministry of Education issued the Academic Regulations on the Research of Philosophy and Social Sciences in Higher Schools (Trial) to regulate related issues. Since then, the 2018 policy document Several Opinions on Further Strengthening the Construction of Scientific Research Integrity was promulgated. At this point, the issue of scientific research integrity has received increasing attention from the 
government and society, and the construction of a scientific research integrity environment is imminent. As far as the existing scientific research integrity legal system is concerned, mainly administrative regulations and normative documents, the legal basis is very weak, and the scientific research integrity legal governance system has not been established. It manifests in the following aspects: First, the lack of scientific research integrity laws. There is no unified standard for scientific misconduct restraint with the significance of higher law, and the normative documents are not coordinated or even conflicted. Second, the lack of rigorous legislation for scientific research integrity, its level of legislation is low, and the penalties for misconduct in scientific research are not clear enough, and the institutionalization and legalization of punishment mechanisms are lacking. The administrative regulatory procedures for scientific misconduct are not open and transparent, and lack good remedies.

The fifth is the legal system of transformation of achievements focuses on dislocation. The use of basic research results should be aimed at promoting economic and social development. According to the Patent Law, the Law on the Transformation of Scientific and Technological Achievements, and the laws and regulations on state-owned assets, financially funded scientific and technological achievements are state-owned assets, and universities and research institutes established by the state have the right to hold and dispose of them. In order to solve the enthusiasm of the scientific and technological achievements of scientific research institutes in the current legal system. In recent years, after the amendment of the Law on the Transformation of Scientific and Technological Achievements, the approval, evaluation and other procedures of the transformation of scientific and technological achievements have been loosened, and incentives have been increased. [9] However, the current legal system still does not solve the basic problem of the nature of the right to financially support scientific and technological achievements. In recent years, the Chinese government has vigorously promoted the reform of institutional mechanisms and stimulated the vitality of innovation subjects. The practical community proposes that scientific and technological personnel should be given ownership of achievements in order to stimulate the enthusiasm of scientific and technological personnel. In fact, it is not legally or logically possible to directly empower scientific research results to scientific researchers, this is because public finance originates from taxpayers, and the scientific and technological achievements based on public financial inputs should benefit the public. As non-profit organizations, universities and research institutions can promote the realization of public interests. The best reform direction is to empower financially-scientific research results to universities and scientific research institutions, and the universities and scientific research institutions will then encourage scientific and technological personnel. Take the United States as an example. In order to solve the difficult problem that the government has difficulty in transforming the results, through the Baydu Act, the ownership of government-sponsored scientific and technological achievements is given to universities or research institutions. This requires universities and scientific research institutions to transform scientific research results, and this ownership is subject to certain restrictions. Generally, universities and scientific research institutions are not allowed to transfer ownership.

\section{Legal Protection to Promote the Development of Basic Research in China}

\subsection{Attach Importance to the Legal Status of the Subject of Basic Research}

The first is to clarify the legal attributes, rights and obligations of scientific research institutions. Clarifying the legal positioning and responsibilities of basic research institutions is conducive to enhancing the ability of innovation sources to supply and thereby promoting the overall prosperity of basic research. Only by clarifying the legal attributes of scientific research institutions can a smooth mechanism be established in the follow-up investment in scientific and technological resources, management of scientific research funds, ownership of results, and reward systems. Therefore, in the amendment of the Science and Technology Progress Law, relevant regulations on the layout, status and role of scientific research institutions in national science and technology research and development and the particularity of the establishment and operation of scientific research and its authority have been added.

The second is to strengthen the role of the National Science Foundation. Basic research is the leading force and strategic engine of national development, and the basic research funding system is a key link in the layout of basic research systems. If the National Science Foundation is weakened, it will be difficult to pay attention to the content of research, and the strategic direction of basic research cannot be funded, which will lead to the marginalization of basic research. At present, in the construction of the national innovation system, there are still problems such as the decentralization, duplication, and inefficiency of scientific and technological resources. The importance of basic research needs to be taken seriously.

\subsection{Legal Guarantee for Long-term Investment in Basic Research}

The first is to ensure the source and form of basic research investment based on the characteristics of basic research. Basic research has the characteristics of high investment, long investment time, high risk, and unclear output effects. Basic research often needs to be guaranteed by public finances. For example, the United States grants financial protection by establishing institutions such as the National Science Foundation and the NIH. In addition, "high-risk, 
high-reward" research is more complex than conventional research and requires longer investment cycles. Funding for research is not appropriate for a project-centric funding mechanism and should be in the form of stable institutional funding. The American Creating Opportunities to Meaningfully Promote Excellence in Technology, Education, and Science Act of 2007 has reserved a portion of the funds by authorizing grant units, which are specifically used as special funds for "high-risk, high-reward " research. The "high-risk, high-reward" research described in the U.S. Competition Act has the following characteristics: It is possible to produce "transformative research" with widespread and far-reaching effects. [10]

The second is that basic research investment in legislation should reflect flexibility and be adjusted as the country develops at different times. The major powers and regions of the world have concentrated their limited human, material and financial resources on the most urgent and needed areas of the country and the most important direction of social development. They have formulated and implemented various levels and types of science and technology development plans, and ensured by legislation. The United States Competition Act increases funding for basic research work in the NSF, NIST laboratories, and DOE science offices, and supports the country's much-needed "high-risk, high-reward" research by authorizing the government. In recent years, various government departments in the United States will release comprehensive scientific and technological strategic plans. The Trump administration has clearly identified five areas for research and development investment in fiscal year 2021: American Security, American Leadership in Industries of the Future, American Energy and Environmental Leadership, American Health \& Bioeconomic Innovation, American Space Exploration and Commercialization. [11] Committed to continue to play the leading role of American technology.

\subsection{The Need for an Independent Scientific Research Funding Financial Management Legal System}

The first is to clarify the legal nature of research funding. Scientific research funding mainly comes from financial input, and financial research funding is mainly used for scientific research activities of higher education institutions, scientific research institutions or non-profit organizations. The management and audit of the use of scientific research funds should be different from the administrative fund management and audit methods of government agencies in the general sense. On the one hand, we must ensure the publicity of scientific research funding, and on the other hand, we must comply with the rules of scientific research and stimulate the enthusiasm of scientific researchers. Therefore, only by clarifying the legal nature of scientific research funding, can it be determined whether the research funding is applicable to corporate accounting standards, public institution accounting standards, or scientific research funding management methods.

The second is the complexity and particularity of financial management of research funding. There are many types of funding for scientific research and development. For example, funding from public budgets, competitively funded scientific research projects, and research funding sources commissioned by companies, etc. The requirements of R\&D tasks and objectives are complex, and the management of scientific research funds, the types of research output results, and audit management cannot be simplified. If the financial management of scientific research funds is carried out through the special appropriation of scientific and technical expenses and scientific and technological expenses, inappropriate and excessive interference in the specific process of scientific research teams and scientific researchers conducting external scientific research activities will inhibit the enthusiasm of scientific researchers. [12]

The third is the urgency of establishing a legal system for research funding. Compared with the US's comprehensive scientific research budget and management laws and regulations system, China has not established a legal system for the use and audit of scientific research funds. The current management of scientific research funds is mainly based on policy documents and departmental regulations, and many of the existing pilot policies are not universally applicable. The lack of a legal system for research funding is an important reason for the frequent occurrence of phenomena such as "loss of state-owned assets and corruption in research" in the scientific research field.

\subsection{Create an Honest Legal Environment and Social Atmosphere Conducive to Basic Research}

The first is the need for legal regulation of scientific misconduct. Contemporary scientific research activities as a means of earning a living make knowledge production directly linked to personal interests, Competition for scientific research resources has also become increasingly fierce, which has led to frequent occurrences of scientific research misconducts. The responsible and ethical conduct of research is essential for the emergence of outstanding results in science and engineering and public trust. It is also essential for the future training of scientists and engineers. Regulate conflicts of interest in scientific research activities, eliminate prejudice and distortion, ensure the objectivity and credibility of scientific research activities, and deal with misconduct in scientific research by introducing legal regulations. The second is that the law of scientific research integrity should reflect the common values of scientific research and a system of behavior norms for social responsibility. The legal system of scientific research integrity is not only reflected in the identification, processing procedures and negative legal consequences of scientific misconduct, but also the scientific spirit and social responsibility should be internalized into the legal system and become the core and soul of the system.

The third is a reasonable legal integrity system for scientific research. Governance of scientific misconduct is a complex systematic project, which requires not only a unified, clear and operable legal and regulatory basis, but also an 
independent scientific misconduct investigation department and procedures to assist with comprehensive scientific integrity education and training. Section 7009 of the The American Creating Opportunities to Meaningfully Promote Excellence in Technology, Education, and Science Act requires that "The Director shall require that each institution that applies for financial assistance from the Foundation for science and engineering research or education describe in its grant proposal a plan to provide appropriate training and oversight in the responsible and ethical conduct of research to undergraduate students, graduate students, and postdoctoral researchers participating in the proposed research project." And so on. The legal governance of scientific research misconduct requires that all parties involved must have accurate positioning, clear responsibilities and concerted efforts.

\subsection{Establish a Stable and Effective Legal System for Protecting and Using Basic Research Results}

The first is that the protection and use of basic research results should be aimed at realizing economic value. Funding basic research by the government is of vital importance to national interests, and the purpose of economic development is achieved by enhancing support for basic research to promote the flow of knowledge and technology to industry. "From the beginning, it was obvious that economic interests rather than academic science interests were the driving forces for the change in government policy." [13]

The second is to attach importance to the protection of intellectual property rights for basic research results. Strengthen the legislation of intellectual property protection, expand the field of intellectual property protection, and strengthen international cooperation and enforcement of intellectual property protection. For example, in terms of strengthening the intellectual property protection legislation and enforcement of drug test data, the European Union has proposed a new intellectual property protection strategy focusing on intellectual property protection in the digital age. [14]

The third is to clarify the ownership of the results of government-funded basic research. The results of government-funded research projects come in different forms, manifested in various forms such as copyright, patent rights, research data, etc. The ownership of government-funded research results lacks legislative provisions and a unified policy at the government level. The practices of different funders are not consistent, making it difficult for basic research results to flow to the market and the private sector. In the 1960s and 1970s, the United States conducted many studies and discussions on federal patent policies. A major concern is the lack of success of the federal government in promoting business adoption of new technologies. To address this issue, the US government has promoted the passage of the Bayh-Dole Act, allowing universities to choose ownership of federally-funded inventions and directly participate in the commercialization process, greatly boosting the enthusiasm of non-profit institutions such as universities.

The fourth is to promote the effective use of basic research results. On the one hand, research results in the field of basic research should be able to effectively promote the growth of social knowledge. On the other hand, the establishment of university technology transfer offices, promotion of government-industry-university-research cooperation, and implementation of active patent policies and technology transfer policies have promoted the commercialization of basic research results. In the US NSF funding, standardized patent terms were specified in the funding agreement. Each grant from the National Science Foundation includes a clause implementing standard patents as part of the general terms and conditions of the grant. [15]

\section{References}

[1] Liu xielin \& He yubing. Basic Research is the Source of China's Industrial Core Technology Innovation [J]. China Soft Science, 2011 (04): 104-117.

[2] Shea D A. Office of Science and Technology Policy (OSTP): History and Overview [J]. Eos Transactions American Geophysical Union, 2016, 57 (10): 739-741.

[3] Ministry of Education of the People's Republic of China, Ministry of Science and Technology of the People's Republic of China \& National Natural Science Foundation of China et al. Several opinions on strengthening basic research work [EB/OL]. http:// www.110.com/fagui/law-75729. 2001-03-06/2020-02-15.

[4] Gong Xu, Fang Xin. Reform and development of basic research in China (1978-2018) [J]. Studies in Science of Science, 2018, 36 (12): 2125-2128.

[5] Kessler F. Contracts of Adhesion--Some Thoughts about Freedom of Contract [J]. Columbia Law Review, 1943, 43 (5): 629-642.

[6] E. Allan Vansworth. United States contract law [M]. China University of Political Science and Law Press, 2004: 22.

[7] Xiao Youdan, Liu Haibo \& Xiao Bin. Research on the Legal Nature of Research and Development Institutions Established by the State - Taking the Chinese Academy of Sciences for Example [J]. China Soft Science, 2018 (8): 1-9.

[8] Liu Haibo \& Liu Jinlei. Policy Analysis and Legislative Research on Governance of Scientific Research Institutions [J]. Journal of Renmin University of China, 2011 (6): 10-16.

[9] Wu tong, Li Zhengfeng \& Zeng Guoping. Evaluation of Basic Research and National Goals [J]. Studies in Science of Science, 2002 (04): 343-347.

[10] U.S. House and Senate. America Creating Opportunities to Meaningfully Promote Excellence in Technology, Education, and Science Act. [EB/OL]. https://science.house.gov/bills/the-america-creating-opportunit ies-to-meaningfully-promote-excellence-in-technology-educat ion-and-science-act-competes. 2007-08-09/2020-02-15.

[11] White House Office of Management and Budget \& White House Office of Science and Technology Policy. FY 2021 Administration Research and Development Budget Priorities. [EB/OL]. https://www.whitehouse.gov/wp-content/uploads/2019/08/FY21-RD-Budget-Priorities.pdf. 2019-08-02/2020-02-15. 
[12] Ask God to do it for me. What is the legal nature of research funding? [EB/OL]. http://m.sohu.com/a/318128438_808513. 2019-06-02/2020-02-15.

[13] Council On Governmental Relations. The Bayh-Dole Act: A Guide to the Law and Implementing Regulations. [EB/OL]. https://www.cogr.edu/sites/default/files/The Bayh-Dole Act-

A_Guide_to_the_Law_and_Implementing_Regulations.pdf. $\overline{20} 1 \overline{5}-07-18 / 20 \overline{2} 0-0 \overline{2}-15$.
[14] Zeng Mingbin \& Li Lingjuan. Challenges Facing China's Basic Research Management System and Countermeasures [J]. Bulletin of the Chinese Academy of Sciences, 2019 (12): 1440-1446.

[15] The National Science Foundation. Proposal and Award Policies and Procedures Guide. [EB/OL]. https://www.nsf.gov/pubs/policydocs/pappg19_1/nsf19_1.pdf. 2019-02-25/2020-02-15. 